\title{
INTERRELASI PEMBANGUNAN HUKUM DAN POLITIK MENUJU TATANAN KEHIDUPAN MASYARAKAT MODERN DAN DEMOKRATIS
}

\author{
Erie Hariyanto \\ (Jurusan Syari'ah STAIN Pamekasan dan Alumni S2 Konsentrasi Ilmu Hukum \\ Unisma Malang)
}

\begin{abstract}
Abstrak
Hukum dan politik mempunyai hubungan erat yang tidak terpisahkan. Hukum merupakan produk politik sedangkan politik terbentuk karena berpegang pada hukum. Semua itu diwujudkan untuk mengatur tatanan hidup bermasyarakat, berbangsa dan bernegara. Tulisan ini mengelaborasi tentang politik dan negara, stabilitas politik dan kepastian hukum, kekuasaan politik demi negara hukum, serta instrumen politik dan politik hukum, sebagai upaya untuk mewujudkan negara yang modern dan demokratis. Untuk mewujudkan tujuan bersama tersebut pemerintah dalam suatu negara senantiasa menciptakan stabilitas politik sehingga keputusan-keputusan hukum dapat dilaksanakan secara konsisten dalam upaya menuju kepada kepastian hukum, demi ketertiban dan kesejahteraan masyarakat. Di samping itu politik hukum yang diterapkan oleh lembaga-lembaga kenegaraan juga harus mampu menampung semua aspirasi yang berkembang dalam masyarakat.
\end{abstract}

\section{Kata Kunci:}

hukum, politik, dan negara.

\section{Pendahuluan}

Hukum dan Politik bagaikan dua sisi koin yang tidak terpisahkan satu dengan yang lainnya karena keduanya memang saling berhubungan. Kenyataannya, hukum merupakan produk politik yang sengaja dibuat untuk mengatur tatanan hidup 


\section{Erie Hariyanto}

bermasyarakat, berbangsa, dan bernegara. Hukum diciptakan untuk kepentingan hidup manusia dalam memenuhi tugas-tugasnya di dunia dan memunaikan amanah untuk hidup bersama secara harmonis, rasional, dan berpedoman kepada hak-hak asasi manusia. Sebagai produk politik, hukum diciptakan oleh negara dan dianggap sah apabila dikukuhkan oleh negara.

Politik hukum suatu negara sebenarnya diformulasikan oleh "tangan-tangan" pemerintah sebagai pihak yang memiliki legitimasi dalam menjalankan roda kenegaraan. Dalam istilah lain dapat dinyatakan bahwanegara berwenang dalam menerbitkan produk hukum yang sesuai dengan corak dan kepentingan politik yang berlaku saat itu dengan tujuan untuk menciptakan suatu aturan yang seharusnya mengarah kepada keadilan dan kesejahteraan. Hukum juga dapat menjadi alat yang dipergunakan untuk menata kehidupan sosial yang penuh dengan gejolak dan dinamika. Franz Magnis Suseno mengatakan bahwa karakter manusia sebagai makhluk sosial mempunyai dimensi politik. Dengan kata lain, manusia adalah makhluk yang mengenal kepentingan individual dan kolektif. Dalam kerangka demikian, tatanan hukum merupakan lembaga penata kehidupan bersama secara normatif sedangkan negara dapat dipandang sebagai lembaga penta kehidupan yang efektif ${ }^{1}$.

Dari pernyataan tersebut dapat dilihat bahwa negara selaku lembaga politik harus secara dinamis melakukan pengaturan terhadap perilaku warga-bangsanya supaya tidak terjadi kekacauan dan pertentangan kepentingan individual dan kelompok satu dengan yang lainnya. Apabila negara tidak mampu secara fungsional melakukannya maka tidak tertutup kemungkinan akan terjadi pertentangan dan pertikaian yang sulit diatasi. Secara politis, aturanaturan hukum diciptakan untuk meng-cover dan meredam pertentangan yang terjadi dalam masyarakat. Oleh sebab itu hukum yang diciptakan menjadi produk politik senantiasa berhubungan dengan perilaku manusia berbasis kebijakan pemerintah. Menurut Moh. Mahfud MD, politik hukum secara sederhana dapat dirumuskan sebagai kebijakan hukum (legal policy) yang akan atau telah dilaksanakan secara nasional oleh pemerintah, mencakup pula

\footnotetext{
${ }^{1}$ Magnis Suseno, Etika Politik (Jakarta: Gramedia, 1987), hlm. 15
} 


\section{Interrelasi Pembangunan Hukum dan Politik Menuju Tatanan Kehidupan Masyarakat Modern dan Demokratis}

pengertian tentang bagaimana politik mengendalikan hukum yang dapat dilihat dari kongfigurasi kekuatan yang ada di belakang pembuatan atau penegakan hukum itu. ${ }^{2}$

Pernyataan itu menunjukkan adanya hubungan kausalitas antara hukum dan politik. Dalam realitas empiris, hukum hadir sebagai refleksi dari konfigurasi politik yang melatarbelakanginya. Kalimat-kalimat yang terangkai dalam bentuk pasal-pasal peraturan perundang-undangan mencerminkan kehendak politik yang saling bersaing. Dalam kenyataannya memang terlihat bahwa politik sangat menentukan "terciptanya" hukum. Dalam perspektif ahli hukum, ada dua pendapat mengenai interrelasi antara hukum dan politik yaitu aliran idealisme dan aliran realisme. Kaum idealis berpedoman kepada das-sollen berpendirian bahwa hukum harus mampu mengendalikan dan merekayasa perkembangan masyarakat, termasuk kehidupan politiknya. Rescue Pound, salah seorang penganutnya, telah lama berpendirian bahwa "law as a tools of the sosial engineering" (hukum sebagai alat rekayasa kehidupan sosial). Ungkapan demikian relatif relevan karena hukum dipandang mampu berfungsi untuk menjamin ketertiban dalam masyarakat. Sebaliknya, kaum realis seperti Savigny berpendirian bahwa hukum selalu berkembang sesuai dengan perkembangan masyarakatnya. Ini berarti bahwa hukum, mau tidak mau, menjadi independent variable atas keberadaan masyarakatnya, terutama didasari atas keadaan dan kecenderungan politik yang sedang berlaku pada saat itu. ${ }^{3}$

Menurut Satjipto Rahardjo, jika dilihat hubungan antara subsistem politik dan subsistem hukum tampak bahwa politik memiliki konsentrasi energi yang lebih besar sehingga hukum selalu berada pada posisi yang lemah. Itu pulalah sebabnya bahwa seorang pakar hukum seperti Sri Sumantri sering mengeluh bahwa perjalanan politik dan hukum, khususnya di Indonesia, ibarat perjalanan kereta api di atas dan di luar relnya. Artinya, banyak sekali praktik politik yang secara substantif bertentangan dengan aturan hukum. ${ }^{4}$

\footnotetext{
${ }^{2}$ Moh. Mahfud MD, Politik Hukum di Indonesia (Jakarta: LP3ES, 1998), hlm.1

${ }^{3}$ Moh. Mahfud. MD, Pergulatan politik dan Hukum di Indonesia (Yogyakarta: Gama Media, 1999), hlm.71.

${ }^{4}$ Satjipto Rahardjo, Beberapa Pemikiran tentang Rancangan antar Disiplin dalam Pembinaan Hukum Nasional (Bandung: Sinar Baru, 1985), hlm.71.
} 


\section{Erie Hariyanto}

Pernyataan itu menunjukkan bahwa keberadaan hukum dipengaruhi oleh iklim politik. Karakter politik yang demokratis akan melahirkan hukum yang demokratis pula, tetapi sebaliknya jika karakter politik otoriter maka hukum yang dilahirkannya juga akan berbentuk otoriter atau konservatif.

Apabila diperhatikan kondisi Indonesia mulai jaman Orde Lama sampai jaman Reformasi sekarang ini, terlihat sekali bahwa kepentingan politik sangat dominan sehingga mampu mengalahkan aturan-atutan hukum yang berlaku. Pemerintah dalam mengambil kebijakan-kebijakan lebih mengutamakan peran politiknya dari pada hukum, dengan tujuan untuk kepentingan kelompok tertentu dan para elit politik pun tampak saling menyalahkan antara satu dengan yang lainnya. Hal ini menandakan bahwa pihak-pihak yang "bermain" di bidang politik tanpa harus peduli pada aturan-aturan hukum. Sebenarnya aturan hukum yang telah dibuat oleh para pendahulu, bertujuan untuk mengatur tatanan hidup, baik bermasyarakat maupun bernegara. Walaupun demikian, karena faktor politis masing-masing lembaga ingin menonjolkan kekuasaannya tanpa memperhatikan substansi hukum dan pada keadaan seperti ini yang dirugikan juga masyarakat karena tidak lagi mendapat perlindungan hukum.

Dari gambaran tesebut penulis pada bagian ini hendak menjelaskan lebih lanjut tentang politik dan negara, stabilitas politik dan kepastian hukum, kekuasaan politik demi negara hukum, serta instrumen politik dan politik hukum yang pada akhirnya nanti untuk mewujudkan negara yang modern.

\section{Politik dan Negara}

Pembicaraan mengenai hukum dan politik tidak dapat terlepas dari kaitan wacana antara politik dan negara karena hukum merupakan produk dari politik negara. Sepanjang sejarah pemikiran manusia mengenai hukum dan politik sebagaimana yang diungkap di muka, terlihat bahwa negara akan mewujudkan harapan para warga negara akan kehidupan yang tertib, adil dan sejahtera. Hal ini baru dapat tercapai jika negara itu diselenggarakan berdasarkan hukum sebagai aturan main. 


\section{Interrelasi Pembangunan Hukum dan Politik Menuju Tatanan Kehidupan Masyarakat Modern dan Demokratis}

Dari sejarah pemikiran manusia mengenai negara, sudah dapat disimak bahwa untuk menghindarkan kehidupan bersama dari kekacauan dan peperangan di antara semua melawan semua, orang telah berusaha untuk mengkristalisasikan kekuatan individual ke dalam kekuasaan mutlak. ${ }^{5}$ Namun usaha yang dilakukan itu banyak yang salah tafsir sehingga tidak lagi memperhatikan kepentingan rakyat, namun memunculkan tirani baru sebagai akibat dari kekuasaan mutlak yang dijalankan oleh pemimpin negara dengan dalih untuk mengatur kehidupan masyarakat.

Untuk meredam kebijakan tersebut maka hukum sebagai alat kontrol harus dipergunakan sebagai acuan, baik oleh rakyat maupun oleh pemerintah dalam melaksanakan jalinan hubungan pergaulan antarsatu sama lain. Dalam hal ini kepastian hukum merupakan syarat bagi suatu negara yang demokratis, dengan mengacu kepada prinsip-prinsip akal sehat dan sekaligus melibatkan aspirasi rakyat atau masyarakat. Pemerintah selaku lembaga politis yang melaksanakan roda kenegaraan harus melakukan kebijakan sesuai dengan ketentuan hukum yang berlaku, dan hukum yang diciptakan itu harus senantiasa memperhatikan kondisi dan perkembangan yang terjadi dalam masyarakat, dalam hal ini suara-suara masyarakat senatiasa menjadi pedoman dalam penciptaan hukum.

Apabila merujuk kepada negara Indonesia, maka dalam pembukaan UUD 1945 telah dijelaskan bahwa Indonesia adalah negara yang berdasarkan atas hukum dan tidak berdasarkan atas kekuasaan. Ini menunjukkan bahwa segala sesuatunya dilaksanakan berdasarkan hukum, baik dalam pelaksanaan hubungan selaku warga negara maupun pelaksanaan tugas-tugas selaku penyelenggara negara.

Dari penjelasan tersebut jelas bahwa hubungan antara hukum dan negara itu tercermin dari proses penyelenggaraan negara itu, baik terhadap warga negaranya maupun terhadap negara lain yang senatiasa harus berpedoman kepada hukum karena hukum itu dibuat oleh negara dengan tujuan untuk menjamin perlindungan terhadap rakyat secara menyeluruh.

\footnotetext{
${ }^{5}$ Budiono Kusumohamidjojo, Ketertiban yang Adil : Problematik Filsafat Hukum (Jakarta: Grasindo, 1999), hlm.148
} 


\section{Erie Hariyanto}

\section{Stabilitas Politik dan Kepastian Hukum}

Fungsi hukum adalah memelihara kepentingan umum dalam masyarakat, menjaga hak-hak manusia dan mewujudkan keadilan dalam hidup bersama. Ketiga fungsi ini tidak saling saling bertentangan tetapi saling mengisi menjadi satu konsep dasar, yakni bahwa manusia harus hidup dalam suatu masyarakat dan bahwa masyarakat itu harus diatur dengan baik. ${ }^{6}$

Selanjutnya dapat direnungkan bahwa tiap-tiap manusia menginginkan ketenteraman di tengah pergolakan-pergolakan hidup. Karenanya orang-orang selalu berusaha untuk mengamankan dirinya terhadap bahaya yang mungkin timbul. Salah satu upaya ke arah itu adalah mengatur kehidupan bersama sedemikian rupa sehingga tidak terjadi sesuatu yang tidak diharapkan. Untuk itu hukum yang ditentukan oleh pemerintah harus mempunyai kepastian berlaku (legalitas).

Pernyataan itu menunjukkan bahwa perlu adanya stabilitas politik oleh pemerintah untuk menuju pada kepastian hukum. Apabila kebijakan atau politik yang dijalankan oleh pemerintah tidak menggambarkan kondisi yang kondusif maka produk hukum yang dihasilkan juga tidak akan dapat diterima oleh semua pihak. Dengan demikian sudah dapat dipastikan bahwa hukum yang akan diterapkan tersebut tidak akan memberikan kepastian hukum kepada semua pihak.

Sebagaimana dikemukakan bahwa melalui hukum manusia hendak mencapai ketertiban umum dan keadilan. Namun harus disadari bahwa ketertiban umum dan keadilan yang hendak dicapai melalui hukum itu hanya dapat dicapai dan dipertahankan secara dinamis melalui penyelenggaraan hukum dalam suatu proses sosial yang diterima oleh masyarakat.

Konsekuensinya hukum itu harus mempunyai kredibilitas sehingga dalam penyelenggaraannya mampu memperhatikan suatu alur konsistensi. Penyelenggaraan hukum yang tidak konsisten tidak akan membuat masyarakat mau mengandalkannya sebagai perangkat kaidah yang mengatur kehidupan bersama. ${ }^{7}$ Konsistensi dalam

6 Theo Huijber, Filsafat Hukum dalam Lintasan Sejarah (Yogyakarta: kanisus, 1982) hlm. 289.

${ }^{7}$ Kusumohamidjojo, Ketertiban, hlm. 150 
Interrelasi Pembangunan Hukum dan Politik Menuju Tatanan Kehidupan Masyarakat Modern dan Demokratis

penyelenggaraan hukum merupakan gambaran dari kepastian hukum Konsistensi diperlukan sebagai acuan bagi perilaku manusia sehari-hari dalam berhubungan dengan manusia lainnya. Acuan perilaku itu diperlukan, karena manusia tidak hidup berdasarkan naluri alamiahnya melainkan terutama berdasarkan akal yang membuat keputusan melalui kehendak yang bebas.

Memang bisa dibayangkan bahwa akal yang bekerja berdasarkan kehendak bebas dapat sampai kepada aneka keputusan yang berbeda atau bersilangan. Untuk itu perlu adanya patokan perilaku sehingga dapat dibedakan mana perilaku yang dapat diterima oleh umum dan mana yang tidak. Oleh karena itu pemerintah selaku penyelenggara negara secara politis harus dapat memberikan patokan atau batasan terhadap produk hukum yang dikeluarkan, sehingga tidak terjadi salah tafsir antara berbagai pihak dan kalangann, demi untuk terciptanya kepastian hukum.

Kepastian hukum harus mempunyai bobot formal maupun materiil. Kinerja formal dihasilkan oleh konsistensi dalam penerapan cara dan prosedur yang relatif sama terhadap suatu perilaku yang menyimpang dari norma hukum. Rawls memberi nilai yang tinggi kepada kinerja formal dari hukum sehingga hukum dapat memberi jaminan bagi keadilan yang substansial. Ungkapan itu menunjukkan bahwa kinerja formal dari hukum tidak dapat dilepaskan dari pengaruh-pengaruh politik karena berhubungan dengan prosedur. Oleh karena itu perangkat pemerintahan yang menjalankan roda kenegaraan harus mampu memberikan cerminan yang pasti bagi masyarakat mengenai penerapan hukum sehingga pemerintah di mata masyarakat mempunyai kredibilitas yang baik dan dapat dipercaya.

Berbeda dengan kepastian hukum formal yang diperoleh melalui kinerjanya, kepastian hukum materiil dihasilkan oleh rasa keadilan yang proporsional sesuai dengan perilaku yang menyimpang tersebut. Kepastian hukum formal menjadi tidak pernah ada jika setahun yang lalu dikenai hukuman pidana sedangkan sebulan yang lalu dikenai sanksi perdata. Demikian juga halnya dengan kepastian hukum materiil menjadi tidak pernah ada jika seorang bendahara Kantor Kepala Desa yang melakukan korupsi tingkat desa dan seorang pejabat tinggi negara eselon satu yang 


\section{Erie Hariyanto}

melakukan korupsi tingkat eselon satu, pada akhirnya sama-sama dikenai pidana penjara misalnya lima tahun. ${ }^{8}$

Di sini terlihat bahwa tidak adanya konsekuensi atau kepastian dari penegakan hukum, baik secara formal maupun secara materil. Dalam contoh tersebut penegak hukum tidak lagi melihat substansi hukum dan tidak pula melihat secara proporsional tindakan yang telah dilakukan oleh seseorang tetapi cenderung menyamaratakan. Peran negara dalam hal ini sangat besar untuk meluruskan sikap dan tindakan penegak hukum sebagai bagian dari proses sosial. Oleh karenanya, penegakan kepastian hukum itu haruslah bertumpu pada dua komponen, yaitu kepastian dalam orientasi bagi masyarakat dan kepastian penerapan hukum oleh penegak hukum.

Ada beberapa faktor yang dapat dipergunakan sebagai acuan untuk menuju kepada kepastian hukum, yaitu :

1. Norma-norma yang jelas menetapkan apa yang diharuskan dan apa yang dilarang. Sebagai gambaran, dapat ditunjukkan bahwa aparat hukum pajak cenderung dapat ditafsirkan berlainan, baik di antara petugas pajak sendiri maupun di antara para wajib pajak. Akibatnya, akan menurunkan tingkat ketaatan dari para wajib pajak di samping juga membuka peluang bagi para petugas pajak untuk menafsirkan pelaksanaan dari berbagai perangkat hukum pajak itu menurut seleranya sendiri.

2. Transparansi hukum yang menghindarkan masyarakat dari "kebingungan normative". Bagian dari suatu transparansi ialah konsistensi dalam tindakan dan ucapan dari para pejabat negara dan penegak hukum. Perbedaan dalam tindakan dan ucapan di antara mereka akan semakin memperdalam "kebingungan normative" di kalangan rakyat karena, di negara mana pun juga, rakyat cenderung memperhatikan kata-kata dan perilaku dari para pejabat/aparat negara dan aparat penegak hukum sebagai acuannya.

3. Kesinambungan tertib hukum yang memberi acuan bagi perilaku di masa mendatang. Jika seorang pejabat tinggi pemerintahan pada suatu ketika menyatakan bahwa pemerintah tidak akan melakukan devaluasi mata uang namun dalam kenyataannya

${ }^{8}$ Ibid., hlm. 152 


\section{Interrelasi Pembangunan Hukum dan Politik Menuju Tatanan Kehidupan Masyarakat Modern dan Demokratis}

kemudian pemerintah melakukan devaluasi, akan terjadi ketidakpercayaan rakyat terhadap kesinambungan tertib hukum. Sebagai hasilnya, rakyat cenderung akan mengembangkan spekulasi sendiri, sekalipun disadari bahwa spekulasi itu menambah beban yang pada akhirnya juga tidak dapat diandalkan.

Penerapan faktor-faktor tersebut sebagai acuan bagi orientasi masyarakat maupun penerapan prinsip-prinsip hukum yang berlaku umum harus dilakukan berdasarkan dua prinsip keadilan, agar tidak mencederai rasa keadilan masyarakat, yaitu prinsip daya laku hukum yang umum serta prinsip kesamaan di hadapan hukum.

Sebagai contoh dapat dikemukakan bahwa ketika Mahkamah Agung Amerika Serikat mengambil keputusan-sepakat dengan perimbangan suara 9 lawan 0 (nol) tentang posisi Presiden Amerika Serikat tidak lebih tinggi dari hukum, dan bahwa Paula Jones yang menggugat Billiam Jefferson Clinton (yang saat itu sedang menjabat sebagai presiden) dapat melanjutkan gugatannya kepada pengadilan. Di situlah kelihatan adanya konsekwensi terhadap penerapan azas kesamaan di hadapan hukum bahwa seorang Presiden Amerika Serikat dapat dituntut melalui pengadilan. Bagaimana pula halnya bila dibandingkan dengan Negara Indonesia? Sampai saat ini belum satu pun Presiden Indonesia yang diduga bersalah dapat diajukan ke pengadilan dengan berbagai alasan yang berbau politis. Begitulah terlihat bahwa tidak adanya kesamaan di muka hukum walaupun tentang persamaan itu telah dituangkan dalam Pasal 27 ayat (1), UUD 1945. Kenyataannya, ketentuan ini tidak mempunyai daya laku.

Jika ada orang tertentu harus dihadapkan ke muka pengadilan karena suatu indikasi pelanggaran hukum namun karena ada aneka kelebihan dan dengan alasan politis maka terhadap orang tersebut melekat semacam kekebalan hukum sehingga dia dibebaskan dari indikasi pelanggaran hukum itu secara politis pula. Dalam hal ini akan didapat suatu kasus di mana prinsip daya laku hukum yang umum sudah dilanggar. Hukum tidak lagi berlaku secara umum dan telah pilih kasih sehingga hukum seperti itu segera memperoleh citra sebagai "seorang ibu tiri." 9

${ }^{9}$ Kusumohadmidjojo, hlm. 156 


\section{Erie Hariyanto}

Dari kenyataan tersebut tertumpu harapan, baik dari komponen-komponen aparat penegak hukum maupun dari masyarakat sendiri, apalagi dari lembaga-lembaga kenegaraan yang menetapkan kaidah hukum, secara sadar mau melaksanakan aturan hukum tersebut demi terciptanya suatu perdamaian dan keadilan di tengah-tengah masyarakat.

Dalam negara hukum, sebagaimana halnya Indonesia, kewenangan pemerintah diselenggarakan berdasarkan atas hukum dan bukan berdasarkan atas kekuasaan. Kesinambungan sikap, konsistensi, dan tindakan dari lembaga-lembaga kenegaraan itu yang sangat menentukan dalam tindakan akan mengakibatkan kaburnya kepastian hukum. Karena lembaga-lembaga kenegaraan senantiasa bertanggung jawab dan berwenang dalam penyelenggaraan hukum, pada akhirnya merupakan produk dari proses politik. Kesinambungan sikap dan konsistensi tindakan mereka juga sangat tergantung dari stabilitas politik.

\section{Kekuasaan Politik Demi Negara Hukum}

Kriteria bagi suatu negara modern adalah apabila kekuasaan rejim dalam suatu negara diselenggarakan berdasarkan hukum. Dengan pengertian bahwa dalam suatu negara hukum, pemerintah yang dibentuk secara demokratis hanya akan melaksanakan kekuasaan politiknya berdasarkan dan terbatas dalam kerangka konstitusi. Dalam kerangka politik, fungsi hukum adalah untuk meluruskan penggunaan kekuasaan agar tidak sewenang-wenang.

Menurut Hegel, negara adalah perwujudan dari gagasan kesusilaan, semangat kesusilaan yang terungkap sebagai kehendak, yang dari dirinya adalah kehendak yang jelas dan substansial, yang memikirkan dan mengetahui, dan melaksanakan apa yang diketahui dan sejauh diketahuinya. Perlu dijelaskan di sini bahwa kesusilaan yang dimaksudkan oleh Hegel harus ditangkap dalam konteks sosial politik dan bukan dalam konteks individual. Dengan demikian, yang dianggap bertentangan dengan kesusilaan adalah kekuasaan yang sewenang-wenang. Sedangkan menurut Roger H. Soltau, negara adalah alat (agency) atau wewenang (authority) yang punya hak 


\section{Interrelasi Pembangunan Hukum dan Politik Menuju Tatanan Kehidupan Masyarakat Modern dan Demokratis}

mengatur atau mengendalikan persoalan-persoalan bersama atas nama masyarakat (The state is an agency in the name of the community).

Negara merupakan integrasi dari kekuasaan politik karena ia adalah organisasi pokok dari kekuasaan politik. Negara adalah agency dari masyarakat yang mempunyai kekuasaan untuk mengatur hubungan-hubungan manusia dalam masyarakat dan menertibkan gejala-gejala kekuasaan dalam masyarakat. Negara juga menetapkan cara-cara dan batas-batas sampai di mana kekuasaan dapat digunakan dalam kehidupan bersama itu, baik oleh individu, golongan atau asosiasi, maupun oleh negara itu sendiri. Dengan demikian ia dapat mengintegrasikan dan membimbing kegiatankegiatan sosial dari masyarakat ke arah tujuan bersama.

Dalam rangka ini boleh dikatakan bahwa negara mempunyai dua tugas, yaitu :

1. Mengendalikan dan mengatur gejala-gejala kekuasaan yang asosial, yakni yang bertentangan satu sama lain agar tidak menjadi antagonisme yang membahayakan.

2. Mengorganisasikan dan mengintegrasikan kegiatan manusia dan golongan-golongan ke arah tercapainya kegiatan asosiasi-asosiasi kemasyarakatan yang disesuaikan satu sama lain dan diarahkan kepada tujuan nasional. ${ }^{10}$

Pengendalian tersebut harus dilakukan berdasarkan sistem hukum dan dengan perantaraaan pemerintah beserta semua alat-alat perlengkapannya. Oleh karena itu kekuasaan politik yang dijalankankan oleh pemerintah harus berdasarkan kepada hukum yang telah ditentukan sebagai aturan mainnya. Bagi negara hukum yang modern maka kaidah hukum yang berlaku umum tersebut harus dirumuskan dalam bentuk konstitusi.

Suatu konstitusi yang baik merupakan produk dari suatu proses politik yang secara demokratis menampung dan menyalurkan aspirasi-aspirasi yang utama, yang sebenarnya mencerminkan pandangan rakyat tentang tata norma, etis sosial, ketertiban umum,

${ }^{10}$ Mirian Budiarjo, Dasar-dasar Ilmu Politik (Jakarta: Gramedia Pustaka Utama, 1997), hlm. 39 


\section{Erie Hariyanto}

keadilan, tata nilai sosial dan budaya, peranan serta hubunganhubungan antarlembaga sosial.

Dengan demikian konstitusi itu diciptakan untuk mengatur dan membatasi tindakan-tinidakan pemerintah dan rakyat dalam melaksanakan tugas dan kewajiban masing-masing. Tentunya konstitusi yang diciptakan tersebut tidaklah statis namun dinamis, yaitu mengikuti perkembangan yang terjadi dalam masyarakat. Suatu konstitusi dapat saja diubah karena tidak sesuai lagi dengan kondisi politik yang ada, misalnya saja UUD 1945 harus mengalami amandemen (perubahan) karena harus disesuaikan dengan alam reformasi.

Dari sini kelihatan bahwa jaminan terhadap negara hukum itu adalah ditentukan oleh dua persoalan, yaitu apakah konstitusinya dibuat melalui proses dan kemudian diratifikasi secara demokratis, serta apakah konstitusi itu ditaati dan dilaksanakan oleh pemerintah maupun oleh rakyat yang diperintahnya secara tersurat maupun tersirat. Jawaban positif terhadap kedua persoalan ini menentukan juga kadar keseimbangan politik yang dihasilkan oleh konstitusi yang bersangkutan.

Dari pernyataan ini dapat dipahami bahwa konstitusi suatu negara hukum harus dibuat berdasarkan keseimbangan politik yang ada sehingga konstitusi itu dapat mengakomodasi semua kalangan dan tidak cenderung menguntungkan salah satu pihak. Disinilan perlu adanya kesamaan pandangan atau persepsi tentang kandungan dari konstitusi yang diciptakan dari berbagai pihak, baik dari unsur masyarakat, partai politik, organisasi sosial maupun dari pemerintah dan lembaga-lembaga kenegaraan lainnya.

\section{Instrumen Politik dan Politik Hukum}

Dalam negara hukum, hukum menjadi alat untuk mencapai cita-cita bersama yang telah disepakati. Juga sebagai alat untuk menyelesaikan berbagai macam bentuk perselisihan, baik dalam masyarakat maupun dalam pemerintahan dan lembaga-lembaga kenegaraan lainnya. Hukum harus bisa diterapkan dalam segala keadaan, tanpa ada perbedaan satu sama lain. Hukum (konstitusi) 


\section{Interrelasi Pembangunan Hukum dan Politik Menuju Tatanan Kehidupan Masyarakat Modern dan Demokratis}

dalam suatu negara adalah hasil dari kesepakatan politik yang dirumuskan bersama untuk menghadapi berbagai persoalan yang terjadi.

Sehubungan dengan hal ini maka suatu negara harus melaksanakan fungsinya, yaitu sebagai berikut:

1. Melaksanakan penertiban (law and order). Untuk mencapai tujuan bersama dan mencegah bentrokan-bentrokan dalam masyarakat maka negara harus melaksanakan penertiban. Dapat dikatakan bahwa negara bertindak sebagai stabilisator;

2. Mengusahakan kesejahteraan dan kemakmuran rakyatnya. Bagi negara yang sedang berkembang fungsi ini sangat penting karena merupakan barometer dari kemajuan suatu negara.

3. Pertahanan. Hal ini diperlukan untuk mengantisipasi berbagai jenis ancaman, baik yang datang dari dalam maupun dari luar.

4. Menegakkan keadilan. Hal ini perlu untuk memberikan perlindungan dan kepercayaan kepada masyarakat.

Beberapa fungsi tersebut harus dilaksanakan oleh suatu negara melalui instrumen (alat) politik yang ada dalam negara, seperti kepolisian, kejaksaaan, kehakiman, dan lembaga-lembaga kenegaraan lainnya sesuai dengan porsi dan tugasnya masingmasing. Pemerintah juga mengemban kewajiban untuk mendorong tegaknya hukum dan keadilan dalam masyarakat. Upaya ini harus dilaksanakan melalui cara-cara administrasi negara yang mencakup kegiatan legislasi dan regulasi yang terencana sehingga terwujud perangkat undang-undang dan peraturan-peraturan yang sesuai dengan konstitusi. Perencanaan itu dilakukan melalui perumusan kebijakan-kebijakan yang mempengaruhi pelaksanaan serta pengembangan hukum sebagai pengejawantahan dari konstitusi. Itulah kegiatan yang disebut sebagai penyelenggaraan politik hukum.

Di Indonesia, politik hukum dirumuskan pada tahap legislasi dalam Undang-Undang Program Pembangunan Nasional (PROPENAS) yang ditetapkan oleh MPR. Seyogyanya undangundang yang dibahas di DPR merupakan respons terhadap manifestasi lanjutan dari PROPENAS, sehingga selayaknya bisa diharapkan bahwa proses pembuatan undang-undang tidak setiap 


\section{Erie Hariyanto}

kali harus mengambil risiko untuk melangkah mundur. Pada tahap eksekutif seyogianya aneka Peraturan Presiden dan Peraturan Menteri merupakan penerapan lanjutan dari undang-undang. Dengan cara demikian diharapkan akan terselenggara suatu politik hukum yang konsisten.

Aneka masalah yang menghinggapi sistem hukum Indonesia sampai lebih dari setengah abad eksistensinya untuk sebagian besar dapat dikembalikan kepada ketidakjelasan politik hukum yang dianut oleh pemerintah. Celakanya, negara yang seharusnya mewakili rakyat justru diwakili secara sempit oleh pemerintah yang dalam masa orde baru malahan lebih mempersitnya lagi menjadi ideologi pembangunan.

Ketidakjelasan politik hukum yang dirumuskan dalam bentuk undang-undang tersebut, dapat menimbulkan penafsiran yang bermacam-macam dalam pelaksanaannya. Kondisi seperti ini menunjukkan bahwa tidak adanya kepastian hukum dalam negara yang bersangkutan. Negara yang tidak memiliki kepastian hukum akan sulit untuk tampil dan bersaing pada tataran global, karena tataran global di masa depan akan semakin bertumpu pada aturan main yang transparan, yaitu aturan hukum yang jelas.

\section{Penutup}

Dari deskripsi artikel tersebut dapat disimpulkan bahwa hukum dan politik mempunyai kaitan sangat erat (interrelationship) yang tidak terpisahkan karena hukum itu merupakan produk politik yang diciptakan untuk mengatur tatanan hidup bermasyarakat, berbangsa dan bernegara guna mewujudkan negara yang modern dan demokratis. Negara sebagai lembaga yang mewujudkan harapan masyarakat akan kehidupan yang tertib, adil dan sejahtera. Melalui pemerintahnya harus mampu menyelenggarakan roda kenegaraan berdasarkan hukum sebagai aturan main dalam mengeluarkan berbagai kebijakan.

Dalam usaha untuk mewujudkan tujuan bersama tersebut pemerintah dalam suatu negara senantiasa menciptakan stabilitas politik sehingga keputusan-keputusan hukum dapat dilaksanakan secara konsisten dalam upaya menuju kepada kepastian hukum, demi 
Interrelasi Pembangunan Hukum dan Politik Menuju Tatanan Kehidupan Masyarakat Modern dan Demokratis

ketertiban dan kesejahteraan masyarakat. Kekuasaan politik yang dijalankan oleh pemerintah bersama lembaga-lembaga kenegaraan lainnya seharusnya sejalan dengan konstitusi yang telah disepakati bersama demi tegaknya negara hukum. Dalam hal ini semua komponen bangsa, baik masyarakat, organisasi sosial dan politik, maupun lembaga legislatif, eksekutif dan yudikatif selaku instrumen politik, harus secara sadar melaksanakan tugas dan kewajiban sesuai dengan aturan hukum.

Di samping itu politik hukum yang diterapkan oleh lembagalembaga kenegaraan juga harus mampu menampung semua aspirasi yang berkembang dalam masyarakat, sehingga peraturan perundangundangan yang diciptakan sebagai penjabaran dari konstitusi harus dirumuskan secara jelas dan transparan, agar dalam pelaksanaannya tidak terjadi kesalahan penafsiran sehingga dapat menimbulkan pertentangan yang dapat merugikan bangsa dan negara. 